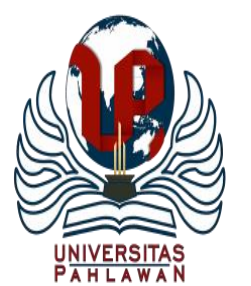

\author{
Jurnal Abdidas Volume 1 Nomor 5 Tahun 2020 Halaman 418 - 423 \\ JURNAL ABDIDAS \\ Community Development Service on Educational and Health Sciences \\ http://abdidas.org/index.php/abdidas
}

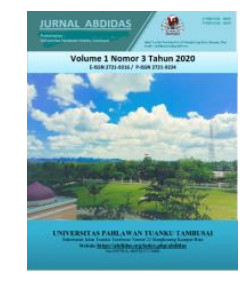

\title{
Edukasi Gizi Cegah COVID-19 dan Pemanfaatan Tusuk Ajaib dalam Upaya Pemilihan Makanan Bebas dari Formalin
}

\author{
Yeffi Masnarivan ${ }^{1}$, Putri Aulia Arza ${ }^{1}$, Hukma Shabiyya ${ }^{1}$, Muhammad Fadhil ${ }^{1}$ \\ Fakultas Kesehatan Masyarakat Universitas Andalas, Indonesia ${ }^{1}$ \\ e-mail : yeffimasnarivan@ph.unand.ac.id, tilla.arza@gmail.com, muhammadfadhilarmen@gmail.com, \\ hshabiyya@gmail.com
}

\begin{abstract}
Abstrak
Keamanan pangan merupakan suatu hal yang harus diperhatikan karena dapat berdampak pada kesehatan, baik bagi anakanak maupun orang dewasa. Menurut data dari Badan Pengawas Obat dan Makanan (BPOM), sepanjang tahun 2012, insiden keracunan akibat mengonsumsi makanan menduduki posisi paling tinggi, yaitu 66,7\%. Kelurahan Koto Baru merupakan salah satu kelurahan yang berada di Kecamatan Lubuk Begalung, Kota Padang. Berdasarkan hasil pengamatan langsung di lapangan cukup tinggi minat masyarakat dalam membeli tahu, akan tetapi masyarakat dalam membeli tidak memperhatikan kondisi tahu tersebut. Untuk itu tim pengabdian tertarik dalam melakukan pengabdian kepada masyarakat tentang edukasi gizi cegah COVID-19 dan pemanfaatan tusuk ajaib dalam upaya pemilihan makanan bebas dari formalin. Pengabmas ini bertujuan untuk melakukan peningkatan pengetahuan masyarakat tentang gizi untuk cegah COVID-19 dan pemanfaatan tusuk ajaib dalam upaya pemilihan makanan bebas dari formalin. Metode pengabdian yaitu melakukan edukasi gizi dengan penyuluhan dan melihat vidio cara memilih makanan bebas dari formalin. Pengabdian diawali dengan perkenalan oleh tim pengabmas. Kegiatan selanjutnya adalah edukasi gizi kepada masyarakat tentang kriteria makanan yang sehat dan aman untuk kesehatan serta menonton vidio cara membuat tusuk ajaib untuk mendeteksi makanan bebas formalin. Selanjutnya membagikan leaflet tentang bahaya formalin dan tanya jawab dengan peserta pengabdian masyarakat. Peserta antusias dalam mengikuti kegiatan.
\end{abstract}

Kata kunci: edukasi gizi, tusuk ajaib, makanan, bebas formalin

\section{Abstract}

Food safety is something that must be considered because it can have an impact on health, both for children and adults. According to data from the Food and Drug Administration (BPOM), throughout 2012, the incidence of poisoning due to eating food occupied the highest position, namely 66.7\%. Koto Baru Village is one of the villages located in Lubuk Begalung District, Padang City. Based on the results of direct observations in the field, the community's interest in buying tofu is quite high, but the community does not pay attention to the condition of the tofu. For this reason, he is interested in providing community service about nutrition education to prevent Covid-19 and the use of magic sticks in an effort to choose food free from formaldehyde. This community service aims to increase public knowledge about nutrition to prevent Covid-19 and the use of magic sticks in an effort to choose food free from formalin. The service method is to carry out nutrition education by giving counseling and watching videos on how to choose formalin-free foods. The service begins with an introduction by the community service team. The next activity is nutrition education to the public about the criteria for healthy and safe food for health and watching videos on how to make magic skewers to detect formalin-free foods. Furthermore, distributing lieflets about the dangers of formaldehyde and questions and answers with community service participants. Participants were enthusiastic in participating in the activity.

Keywords: nutrition education, magic prick, food, formalin free

Copyright (c) 2020 Yeffi Masnarivan, Putri Aulia Arza, Hukma Shabiyya, Muhammad Fadhil

$\square$ Corresponding author :

Address : Padang, Sumatera Barat, Indonesia

Email : yeffimasnarivan@ph.unand.ac.id

Phone : 085274343479

DOI : https://doi.org/10.31004/abdidas.v1i5.95

ISSN 2721-9224 (Media Cetak)

ISSN 2721-9216 (Media Online) 


\section{PENDAHULUAN}

Keamanan pangan merupakan suatu hal yang harus diperhatikan karena dapat berdampak pada kesehatan, baik bagi anak-anak maupun orang dewasa (Oktafa et al., 2018). Menurut data dari Badan Pengawas Obat dan Makanan (BPOM), sepanjang tahun 2012, insiden keracunan akibat mengonsumsi makanan menduduki posisi paling tinggi, yaitu 66,7\%, dibandingkan dengan keracunan akibat penyebab lain, misalnya obat, kosmetika, dan lain-lain (BPOM RI, 2012).

Salah satu penyebab keracunan makanan adalah adanya cemaran kimia dalam makanan tersebut. Kasus cemaran kimia yang masih sering ditemui adalah adanya kandungan bahan-bahan berbahaya seperti formalin, boraks, dan pewarna tekstil dalam makanan. Bahan-bahan tersebut tidak seharusnya terdapat dalam makanan karena dapat membahayakan kesehatan, namun dengan alasan untuk menekan biaya produksi dan memperpanjang masa simpan, banyak produsen yang masih menggunakan bahan-bahan tersebut. Jenis makanan yang seringkali mengandung bahan berbahaya tersebut salah satunya adalah tahu yang sering dikonsumsi dalam keluarga (Sumantri, 2007).

Proses pembuatan tahu dilakukan dengan cara menggumpalkan menggunakan bahan-bahan tertentu. Bahan yang biasa digunakan untuk menggumpalkan tahu adalah garam $\mathrm{CaSO}_{4}$. Beberapa penyimpangan yang dilakukan produsen pabrik tahu, salah satunya di Kabupaten Bogor yang menggunakan bahan kimia jenis boraks. Kasus ini dapat dijerat dengan Pasal 136 huruf b Pasal 75 ayat 1 UU RI NO. 18 Tahun 2012 tentang
Pangan dengan ancaman hukuman paling lama 5 tahun atau denda Rp 10 miliar (Sudarno, 2017).

Semakin berkembangnya pabrik pembuatan tahu maka akan semakin mudahnya masyarakat dalam mendapatkan tahu, sehingga akan semakin banyak masyarakat mengkonsumsi tahu. Akan tetapi dalam membeli tahu masyarakat tidak mengetahui bagaimana cara memilih tahu yang sehat dan bebas dari bahan yang berbahaya.

Menurut Preventive and Care (PNC) melaporkan bahwa formalin dan boraks digunakan menjadi bahan tambahan dalam pembuatan tahu, dimana formalin digunakan sebagai pengawet dan boraks digunakan sebagai campuran pada tahu untuk mendapatkan bentuk yang bagus, kenyal, tekstur padat atau tidak mudah hancur. Formalin dan boraks adalah bahan pengawet yang sangat berbahaya apabila ditambahkan dalam makanan. Salah satu makanan yang sering ditambahkan formalin dan boraks adalah tahu (Nasution et al., 2018).

Penelitian oleh Badan Pengawas Obat dan Makanan Indonesia (2010), penggunaan formalin pada ikan dan hasil laut menempati peringkat teratas yakni, 66\% dari total 786 sampel, sementara mi basah menempati posisi kedua dengan $57 \%$, tahu berada di urutan ketiga yakni 16\% (Habibah, 2013). Menurut Poma (2013) pangan yang aman harusnya menggunakan bahan tambahan yang oleh pemerintah dinyatakan aman untuk digunakan pada produk pangan. Zat berbahaya yang dilarang digunakan pada pangan yaitu formalin dan boraks yang menyebabkan bahaya bagi kesehatan misalnya mual, muntah 
diare, luka pada ginjal, paru, dan kanker (Kaligis et al., 2017).

Koto Baru merupakan salah satu kelurahan yang berada di Kecamatan Lubuk Begalung, Kota Padang. Berdasarkan hasil pegamatan langsung dilapangan cukup tinggi minat masyarakat dalam membeli tahu, akan tetapi masyarakat dalam membeli tidak memperhatikan kondisi tahu tersebut. Untuk itu tertarik dalam melakukan pengabdian kepada masyarakat tentang edukasi gizi dan pemanfaatan tusuk ajaib dalam upaya pemilihan makanan bebas dari formalin.

Pengabmas ini bertujuan untuk melakukan peningkatan pengetahuan masyarakat tentang gizi untuk cegah covid-19 dan pemanfaatan tusuk ajaib dalam upaya pemilihan makanan bebas dari formalin.

\section{METODE}

Untuk meningkatkan derajat kesehatan masyarakat dalam mengkonsumsi makanan yang sehat maka dilakukan edukasi gizi tentang tatacara memilih makanan jajanan yang sehat yang bebas dari formalin dan aman serta peningkatan pengetahuan tentang gizi seimbang, terutama pada masa pandemi, sehingga diharapkan akan terjadi peningkatan status gizi dalam keluarga di Koto Baru. Maka tim pengabmas melakukan dengan metode yang dapat dilihat pada Tabel 1 .

\section{HASIL DAN PEMBAHASAN}

Kegiatan pengabdian masyarakat dilaksanakan pada hari Senin 11 Juli 2020. Kegiatan pengabdian masyarakat dilaksanakan di Kelurahan Koto Baru Nan XX, Kecamatan Lubuk Begalung, Kota Padang. Kegiatan ini dihadiri oleh Ketua PKK, tenaga TKSK kecamatan dan seluruh Kader Kelurahan Koto Baru Nan XX dengan menerapkan protokol kesehatan. Adapun alasan kader yang diedukasi agar nantinya para kader bisa menyebar luaskan informasi ini kepada masyarakat sekitar.

Kegiatan diawali dengan perkenalan tim pengabdian masyarakat. Tim juga menjelaskan maksud dari kegiatan pengabdian masyarakat kepada peserta.

Setelah perkenalan, dilakukan pre-test untuk materi pertama yaitu edukasi gizi cegah COVID19 dan cara memilih makanan jajanan yang sehat yang bebas dari formalin dan aman.

Tabel 1. Metode Kegiatan

\begin{tabular}{|c|l|l|}
\hline No. & Kegiatan & Langkah-Langkah Solusi \\
\hline 1. & $\begin{array}{l}\text { Edukasi gizi cegah COVID-19 dan cara } \\
\text { memilih makanan jajanan yang sehat yang } \\
\text { bebas dari formalin dan aman }\end{array}$ & $\begin{array}{l}\text { Memberikan edukasi gizi cegah COVID-19 kepada } \\
\text { masyarakat dan edukasi kriteria makanan yang sehat dan } \\
\text { aman untuk kesehatan dengan metode penyuluhan dan } \\
\text { pemberian leaflet. } \\
\text { Melatih masyarakat dalam membuat tusuk ajaib untuk } \\
\text { mendeteksi tahu terbebas dari formalin dengan menonton } \\
\text { vidio. }\end{array}$ \\
\hline 2. & Edukasi gizi tentang gizi seimbang & $\begin{array}{l}\text { Memberikan edukasi gizi kepada masyarakat tentang gizi } \\
\text { seimbang melalui media bergambar yaitu "Tumpeng Gizi } \\
\text { Seimbang" dan "10 Pesan Gizi Seimbang". }\end{array}$ \\
\hline
\end{tabular}




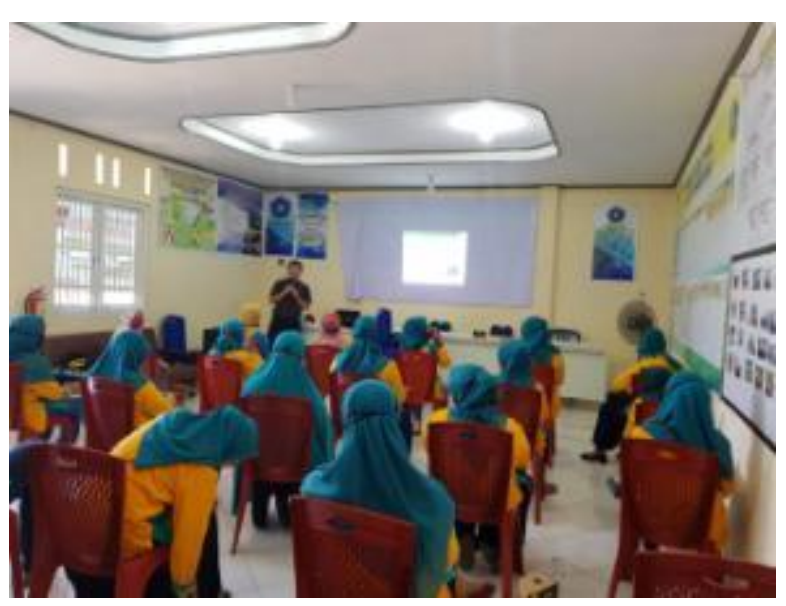

Gambar 1. Penyuluhan Materi Pertama dan Menonton Vidio

Pada masa pendemi COVID-19, kita harus meningkatkan sistem kekebalan tubuh yang merukan kekuatan pertahanan tubuh melawan bakteri, virus dan organisme penyebab penyakit yang mungkin kita sentuh, konsumsi dan hirup setiap hari. Sehingga meningkatkan daya tahan tubuh adalah salah satu kunci agar tidak tertular virus COVID-19. Adapun hal-hal yang dapat meningkatkan daya tahan tubuh adalah 1) makan makanan bergizi seimbang serta jangan lupa minum air putih 8 gelas sehari, 2) cuci tangan dengan air mengalir dan sabun, 3) rutin berolahraga.

Cuci tangan lebih sering dilakukan terutama setelah melakukan kegiatan seperti pada saat sesampainya di rumah atau di tempat kerja, setelah batuk atau bersin, sebelum makan, sebelum menyiapkan makanan dan minuman dan setelah buang air besar dan kecil. Olah raga tetap bisa dilakukan pada saat pembatasan fisik dengan cara berusahalah untuk bergerak agar sistem kekebalan tubuh dalam kondisi prima, misalnya dengan berjalan kaki atau lari di sekitar rumah, berkebun atau melakukan aktivitas fisik di rumah dengan menonton dan mengikuti video olahraga.

Pada kegiatan ini tim pengabdi juga mengajak kader untuk melakukan adaptasi kebiasaan baru agar tetap produktif dan aman dari COVID-19 seperti yang anjurkan pemerintah yaitu dengan cara 1) jika sedang flu dirumah saja, 2) sedia handsanitizer kemana-mana, 3) tidak lupa pakai masker, 4) tetap jaga jarak, 5) sering cuci tangan pakai sabun dengan air mengalir, 6) setibanya di rumah lansung mandi, 7) say hello saja tidak bersalaman, 8) gunakan uang elektronik, 9) jaga jarak di kendaraan umum, dan 10) balita dan lansia di rumah saja.

Selain itu tim pengabmas juga memaparkan bagaimana cara memilih makanan yang bebas dari formalin dengan menggunakan alat tusuk. Biasanya yang diketahui oleh masyarakat untuk menentukan bahan makanan tidak berformalin atau boraks hanya dengan cara dilihat tidak dihinggapi lalat, jika ditekan tidak keras atau lembek, awet beberapa hari dan tidak mudah busuk. Padahal sebenarnya ada cara mudah yang jarang diketahui oleh masyarakat yaitu dengan cara memanfaatkan kunyit dan alat tusuk (tusuk gigi), dimana langkahnya tusuk gigi ditusukkan ke kunyit lalu tusuk gigi akan bewarna kuning, lalu ditusukkan ke makanan yang akan kita uji, jika makanan tersebut mengandung formalin atau boraks maka warna kuning pada tusuk gigi akan berubah warna menjadi warna merah bata, akan tetapi jika bahan makanan tersebut tidak mengandung formalin/boraks maka tusuk gigi tetap bewarna kuning. Hal ini sangat mudah diterapkan, karena menggunakan alat yang biasanya sudah ada di 
dalam rumah. Materi ini dilengkapi dengan vidio tutorial cara membuat tusuk ajaib dan mendeteksi makanan bebas dari formalin dan bahan berbahaya.

Materi selanjutnya yaitu tentang edukasi gizi tentang gizi seimbang. Edukasi ini didukung dengan media bergambar yaitu tumpeng gizi seimbang dan 10 pesan gizi seimbang yang dikeluarkan oleh Kementrian Kesehatan.

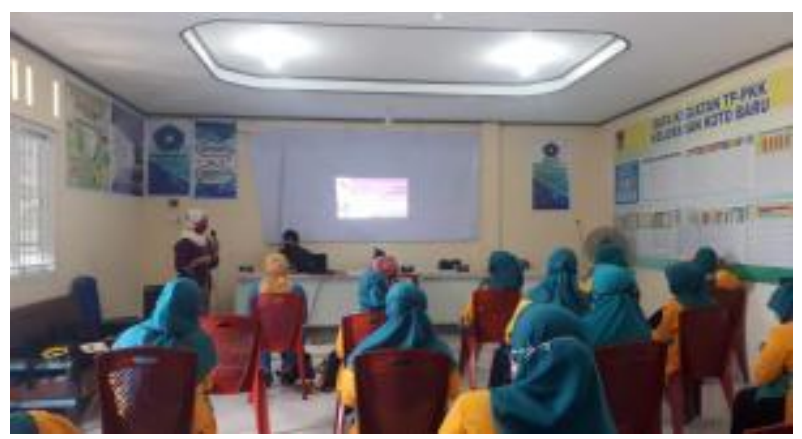

Gambar 2. Penyuluhan Materi Kedua dan Penggunaan Media Bergambar

Pada sesi ini juga dijelaskan tentang bahaya kandungan formalin pada makanan dan dampaknya terhadap kesehatan. Ada beberapa bahan kimia berbahaya pada makanan dan minuman seperti pewarna tekstil, boraks dan formalin. Untuk itu penting kita memilih jajanan sehat dengan cara jajanan harus bersih, aman dan bergizi.

Adapun dampak formalin terhadap kesehatan secara akut efek pada kesehatan manusia lansung terlihat seperti iritasi, alergi, kemerahan, mata berair, mual, muntah, rasa terbakar, sakit perut dan pusing. Sedangkan secara kronik efek pada kesehatan manusia terlihat setelah terkena dalam jangka waktu yang lama dan berulang seperti iritasi kemungkinan parah, mata berair, gangguan pada pencernaan, hati ginjal, pankreas, sistem saraf pusat, menstruasi dan pada hewan percobaan dapat menyebabkan kanker sedangkan pada manusia diduga bersifat karsinogen (menyebabkan kanker).

Mengkonsumsi bahan makanan yang mengandung formalin, efek sampingnya terlihat setelah jangka panjang, karena terjadi akumulasi formalin dalam tubuh. Selain itu tim juga memaparkan cara mudah/langkah utama untuk mengurangi kadar formalin pada makanan.

Berdasarkan pengakuan dari salah seorang kader yaitu Ratna Sari menyempaikan bahwa "edukasi ini sangat banyak manfaatnya apa lagi saat ini sedang masa pandemi informasi kesehatan yang seperti ini kita sangat butuhkan, kami banyak dapat ilmu baru yang sebelumnya kami belum pernah ketahui terutama cara memilih makanan yang bebas dari formalin".

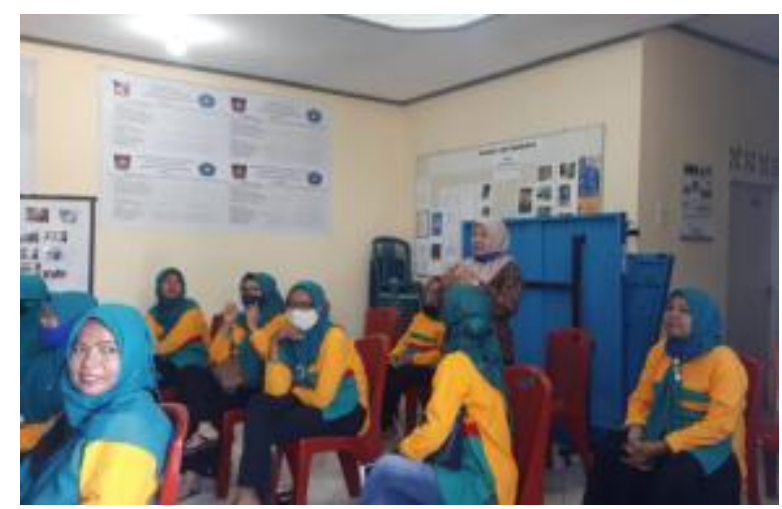

Gambar 3. Diskusi dan Antusias Peserta Mengikuti Kegiatan

\section{SIMPULAN}

Berdasarkan hasil kegiatan edukasi gizi di Kelurahan Koto Baru Nan XX dapat meningkatkan pemahaman kader tentang gizi yang baik untuk cegah COVID-19 dan pemanfaatan 
tusuk ajaib dalam upaya pemilihan makanan bebas dari formalin. Sehingga dengan adanya peningkatan pengetahuan kader juga dapat disampaikan ke masyarakat sekitar nantinya.

\section{UCAPAN TERIMA KASIH}

Terima kasih diaturkan kepada Fakultas Kesehatan Masyarakat Universitas Andalas yang telah mendanai kegiatan ini melalui dana DIPA FKM Universitas Andalas tahun 2020, sehingga dapat terlaksananya kegiatan ini dengan mitra Kelurahan Koto Baru Nan XX Kecamatan Lubuk Begalung Kota Padang tentang edukasi gizi cegah COVID-19 dan pemanfaatan tusuk ajaib dalam upaya pemilihan makanan bebas dari formalin. Terima kasih kami ucapkan juga kepada mitra yang telah bekerja sama sehingga tercapainya tujuan yang diharapkan.

\section{DAFTAR PUSTAKA}

BPOM RI. (2012). Laporan Tahunan 2012. Badan Pengawas Obat dan Makanan.

Habibah, T. P. Z. (2013). Identifikasi Penggunaan Formalin Pada Ikan Asin Dan Faktor Perilaku Penjual Di Pasar Tradisional Kota Semarang. Unnes Journal of Public Health., 2(3), $1-10$. https://doi.org/10.15294/ujph.v2i3.3031

Kaligis, P. A. ., Langi, T. M., \& Tuju, T. D. J. (2017). Survei Penggunaan Formalin Dan Boraks Pada Pedagang Bakso Tusuk Di Sekolah Dasar Kecamatan Wenang Dan Kecamatan Malalayang. Cocos, 1(4).

Nasution, H., Alfayed, M., Ulfa, R., Mardhatila, A., Kimia, P., Mipa, F., \& Riau, U. M. (2018). Analisa Kadar Formalin Dan Boraks Pada Tahu Dari Produsen Tahu Di Lima Kecamatan Kota Pekan Baru. Jurnal Photon, $8(2)$.
Oktafa, H., K, R. N., \& Retnowati, N. (2018). Perbaikan Produksi dan Edukasi Keamanan Pangan Jajanan Anak Sekolah ( PJAS ) di Lingkungan SDN Kecamatan Sumbersari Kabupaten Jember. Seminar Nasional Hasil Penelitian Dan Pengabdian Masyarakat 2018, 112-116.

Sudarno, A. (2017). Gunakan Boraks, Pabrik Tahu di Bogor Digerebek. Liputan 6. https://www.liputan6.com/news/read/297311 5/gunakan-boraks-pabrik-tahu-di-bogordigerebek

Sumantri, A. R. (2007). Analisis Makanan. Gajah Mada University Press. 